\title{
Po sledeh postsocialističnega prestrukturiranja mest: spreminjajoča se središča $v$ srednje- in vzhodnoevropskih prestolnicah
}

Hitre politične in gospodarske spremembe po padcu socializma so povzročile dinamične procese urbanega prestrukturiranja v mestih, pri čemer so stare vzorce in modele rasti zamenjali tisti, pri katerih sta bila kapital in tržno gospodarstvo ključna za rast in razvoj. Preobrazba v tržno gospodarstvo in ponovna uvedba lastništva zemljišč sta zahtevali nov, decentralizirani sistem odločanja, kar je neposredno vplivalo na zgradbo in obliko mest. Med urbanimi preobrazbami so prišle jasno do izraza spremembe v lokacijskih vzorcih trgovskih objektov v mestih, ki so ponazarjale različne vzorce prostorske organizacije postsocialističnih mest. $\mathrm{V}$ članku avtorja preučujeta in predstavita nekatere posebnosti te preobrazbe v Bukarešti, Budimpešti, Pragi in Sofiji pred padcem socializma in po njem. Na podlagi analize izbranih mest predstavita procese postsocialističnega prostorskega prestrukturiranja, pri čemer preučujeta spremembe njihovih središčc, ki so povzročile razdrobljenost mest in razpadanje urbanega tkiva. V primerjalni študiji je poleg tega prikazano, kako se v mestih s podobno preteklostjo lahko pojavijo različni razvojni vzorci.

Ključne besede: središča, decentralizacija, fragmentacija, obrobja, postsocialistična mesta 


\section{Uvod}

Nenaden prehod iz socializma je močno vplival na preobrazbeno dinamiko ter jakost razvoja večine srednje- in vzhodnoevropskih mest. Ponovna uvedba lastništva in začetek privatizacije sta bila ključna dejavnika, ki sta prispevala k prostorskemu prestrukturiranju mest (Harloe, 1996; Nedovic-Budic idr., 2006; Stanilov, 2007; Hoxha idr., 2014, in Tsenkova, 2014). Kriza urbanizma kot posledica tega prestrukturiranja je pomenila nenehno evolucijo in prilagajanje ter ni bila omejena samo na mestno gradnjo, ampak je vključevala tudi širše politične in družbenoekonomske vidike (Koželj, 1992). Ti procesi so povzročili večplastne urbane preobrazbe, ki so vplivale na zaposlovanje, stanovanjski trg, naložbe in strukturo prebivalstva $\mathrm{v}$ mestih.

Med socializmom je rast mest povzročila ozemeljsko širitev teh, medtem ko je bilo v mestnih središčih opaznih manj fizičnih sprememb (Musil, 1993). Urbana preobrazba postsocialističnih mest je še okrepila trende prostorske razpršenosti. Mesta so še naprej širila svoja predmestja ter $s$ tem še dodatno prispevala $\mathrm{k}$ suburbanizaciji in razvoju mestnega obrobja kot posebnega vidika rasti mest (Koželj, 2007). Na suburbanizacijo so vplivali politični in gospodarski dejavniki (Kok in Kovacs, 1999), obrobja mest $v$ tranziciji pa so začela rasti kmalu po letu 1990, ko so se tudi ljudje $\mathrm{v}$ večjem številu začeli preseljevati na obrobje. Uvedba tržnega gospodarstva, vse večji interesi nepremičninskih investitorjev in načrtovalske pobude občin, ki so mejile na glavna mesta, so povzročili nastanek sosesk z enodružinskimi hišami, ki so bile za številne najbolj zaželena stanovanjska izbira (Leetmaa in Tammaru, 2007). Novi naselitveni vzorci niso vplivali samo na stanovanjski trg v mestih, ampak tudi na njihovo družbeno in prostorsko segregacijo ter prebivalstveno strukturo. Pojav neformalnih naselij v istem obdobju je še dodatno prispeval $k$ težavam, povezanim $z$ družbeno izključenostjo, zagotavljanjem stanovanj in prostorskim načrtovanjem (Tsenkova, 2010, ter Mandič in Filipovič Hrast, 2015).

Sočasno $s$ procesi prostorskega prestrukturiranja je mestno središče izgubljalo stanovanjsko funkcijo in se spreminjalo bolj v turistično znamenitost kot $\mathrm{v}$ bivalni prostor (Kádár, 2013). Hkrati je obrobje postalo privlačnejše zaradi trgovskih dejavnosti, ki so bile uvedene za zadovoljevanje potreb lokalnih prebivalcev. $S$ tem je postala preobrazba trgovskih objektov v mestih eden glavnih vidikov preobrazbe (Sykora, 1998; Sailer-Fliege, 1999; Hirt in Kovachev, 2006, ter Stefanovska in Koželj, 2012). Mestno obrobje se je izkazalo za primernejšo lokacijo za nove programske strukture, ki so popestrile nove mestne predele. $\mathrm{V}$ novih središčih, kjer je ogromno pisarn in trgovskih objektov, so se začele kopičiti potrošniške storitve in ustvarile so se nove oblike urbanih subjektov. Čeprav so bila nova središča na obrobju, niso bila ločena od starega mestnega središča, ampak so z njim sobivala; to so delno omogočale boljše povezave med središčem mesta in njegovim predmestjem.

Te spremembe so vsekakor pospešili procesi odločanja, ki so bili na novo uvedeni v okviru postsocialističnega načrtovanja ter so v končni fazi preobrazili mestno pokrajino in dojemanje mest. Urbanistične spremembe so bile glavno gonilo prostorske preobrazbe v mestih. Načrtovanje se je spremenilo v proces, ki so ga usmerjali investitorji in trg ter ga je bilo pogosto težko nadzirati, kar je še dodatno prispevalo h krizi načrtovalske legitimnosti (Kos, 2010). Poleg tega je centralistični načrtovalski sistem zamenjal decentralizirani sistem, ki je z različnimi zakonodajnimi spremembami dal več moči lokalni upravi, kar je prispevalo k prostorskemu neredu in neenakomernemu urbanemu razvoju (Tsenkova, 2011).

V članku avtorja preučujeta lokacijske vzorce središč z vidika urbane preobrazbe postsocialističnih evropskih mest. Izraz »središče « se nanaša na koncentracijo trgovskih dejavnosti in osrednjih mestnih funkcij, ki na določeno lokacijo privlačijo veliko število ljudi. Na podlagi primerjalne raziskave so analizirani značilnosti, razvoj in lokacijski vzorci središč, zgrajenih v Bukarešti, Budimpešti, Pragi in Sofiji pred padcem socializma in po njem.

Glavni cilj je poudariti prostorsko prestrukturiranje mest ter predstaviti odnose med lokacijskimi vzorci središč in urbanističnimi procesi in njihovo dinamiko. $S$ preučevanjem teh vidikov želita avtorja prispevati $\mathrm{k}$ boljšemu razumevanju urbane preobrazbe po padcu socializma, pri čemer je glavni poudarek na prostorskem prestrukturiranju mest na podlagi njihovih spreminjajočih se središč. Glavni raziskovalni vprašanji se glasita: kateri lokacijski vzorci so bili za središča v teh mestih značilni pred padcem socializma in po njem in kaj je vplivalo na pojav središč v postsocialističnem obdobju.

V prvem poglavju je predstavljen kratek pregled urbane preobrazbe v srednje- in vzhodnoevropskih prestolnicah. V drugem poglavju so na podlagi lokacijskih vzorcev središč preučeni prostorsko prestrukturiranje in središča, ki so bila v štirih obravnavanih mestih zgrajena med socializmom. V tretjem poglavju avtorja preučujeta nastajajoča središča in lokacijske vzorce, na podlagi katerih predstavita določene vidike postsocialistične urbane preobrazbe. V sklepu so podane končne ugotovitve o spreminjajočih se središčih ter njihovih lokacijskih vzorcih pred spremembo in po njej, pri čemer so predstavljene podobnosti in razlike v vzorcih njihove razpršenosti. 


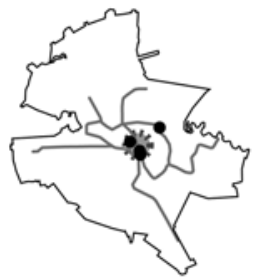

a

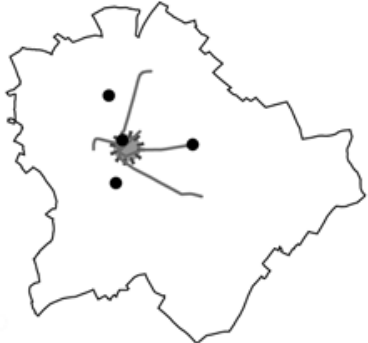

b

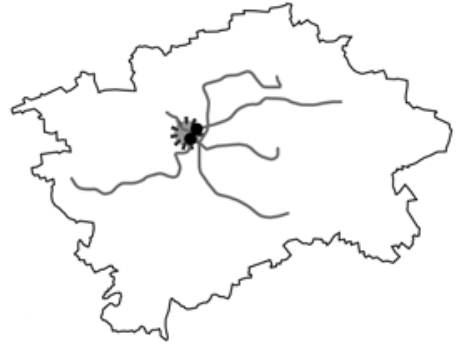

C

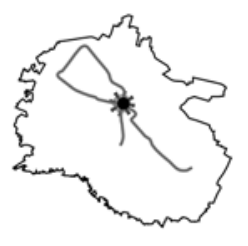

d

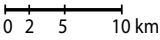

Slika 1: Središča, zgrajena pred letom 1989 v (a) Bukarešti, (b) Budimpešti, (c) Pragi in (d) Sofiji (ilustracija: Jasna Mariotti).

Opomba: Vsa mesta so prikazana v istem merilu, pri čemer je predstavljeno njihovo trenutno upravno in načrtovalsko območje. Risbe poleg tega prikazujejo trenutne proge podzemne železnice $v$ teh mestih ter njihova stara jedra in središča, zgrajena med socializmom.

\section{Prostorsko prestrukturiranje mest med socializmom}

Med socializmom so bili za mesta značilni vzorci rasti, ki so bili posledica osrednje državne ureditve. Ena od glavnih značilnosti tovrstne ureditve je bila ukinitev zasebnega lastništva (Szelenyi, 1996, in Musil, 2005), ki je močno vplivala na načrtovanje in razvoj mest.

$\mathrm{V}$ tem obdobju je delež mestnega prebivalstva rastel in prebivalstvo $v$ glavnih mestih se je povečevalo. To je bila posledica urbanizacijskih politik in strategij socialistične državne ureditve, ki so vključevale celostno načrtovanje in razporeditev industrije v mestih - sestavni del razvoja socialistične družbe (Musil, 1980). Med socializmom se je prebivalstvo v Bukarešti povečalo za $312 \%$, v Sofiji za $228 \%$, v Pragi za $129 \%$ in v Budimpešti za $123 \%$ (World population prospects, 2008). Za naraččajoče prebivalstvo so bile v predmestjih zgrajene stanovanjske soseske, ki so povečale ozemeljski obseg in korenito spremenile prostorsko konfiguracijo mest. Montažna gradnja je pospešila razvoj mestnega obrobja, pri čemer so nastale gosto pozidane soseske, ki so zmanjšale stanovanjski primanjkljaj. Neobstoj nepremičninskega trga in osrednje nadziran načrtovalski sistem sta vplivala na vzorce urbanega razvoja in tako omogočila opisano preobrazbo.

Urbanizem je bil omejen na izpolnjevanje osrednje koordiniranih državnih ideologij (Maier, 1998, in Golubchikov, 2004). V tem obdobju je deloval $\mathrm{v}$ sistemu, $\mathrm{v}$ katerem so bila zemljišča nacionalizirana, osrednje vlade pa so bile odgovorne za odločanje na vseh ravneh; to je pripeljalo do močno nadziranega urbanega razvoja. Namen načrtovalskih odločitev, ki so se sprejemale na osrednji ravni, je bila uveljavitev koncepta središč, ki je temeljil na zamisli mesta s sekundarnimi in terciarnimi središči. Te vizije pa niso bile skoraj nikoli uresničene, saj je bil glavni poudarek vseskozi na stanovanjih v mestih, ki naj bi zadovoljila potrebe naraščajočega prebivalstva in povečala stopnjo urbanizacije na državni ravni. Tovrstne odločitve so bile ključne za oblikovanje monocentričnega mesta z močnim središčem, v katerem so bile vse glavne mestne funkcije.

Trgovski centri v Bukarešti, Pragi in Sofiji, ki so bili zgrajeni med socializmom, so bili tesno povezani z mestnim središčem ali pa so se tam tudi nahajali (slika 1). Njihovo lokacijo je določila država in tako kot vsa druga poslopja v mestu so bili v državni lasti. Za vsa štiri preučevana mesta so značilni lokalizirani vzorci razpršenosti središč, zgrajenih pred letom 1989; bila so maloštevilna, nahajala pa so se blizu topografskih in zgodovinskih mestnih središč. $S$ tem so bili tudi potrošniški vzorci v teh mestih lokalizirani in močno nadzirani, skupaj z blagom, ki se je prodajalo. Kljub temu so bile stavbe mojstrovine socialistične arhitekture in miselnosti (slika 2).

Blagovnica Kotva v Pragi, zgrajena med letoma 1966 in 1974, je bila prva blagovnica, ki je bila tam zgrajena med socializmom (slika 2c). Ob dokončanju je bila največja blagovnica na Češkoslovaškem. Kotva je primer socialistične arhitekture, saj je zgrajena iz heksagonalnih prizem, naloženih druga na drugo, njeno razgibano pročelje pa je izjemen primerek brutalizma. Stavba je bila zgrajena iz industrijskih surovin, kot so železo, steklo in beton, in čeprav stoji v zgodovinski mestni soseski, njena kompleksna konstrukcija močno izstopa. Kmalu po odprtju je postala mestna ikona, zdaj pa je spomeniško zaščitena. Drugi nakupovalni center, ki je bil v Pragi zgrajen med socializmom, je blagovnica My na Narodni aveniji (češ. Národni třída). Zgrajena je bila leta 1978 in je izvrsten primerek češke arhitekture iz 70. let 20. stoletja. Tudi ta stavba je spomeniško zaščitena. $V$ nasprotju s Kotvo ima razmeroma preprosto linearno konstrukcijo, ki pa je še vedno izjemna. Nakupovalni 

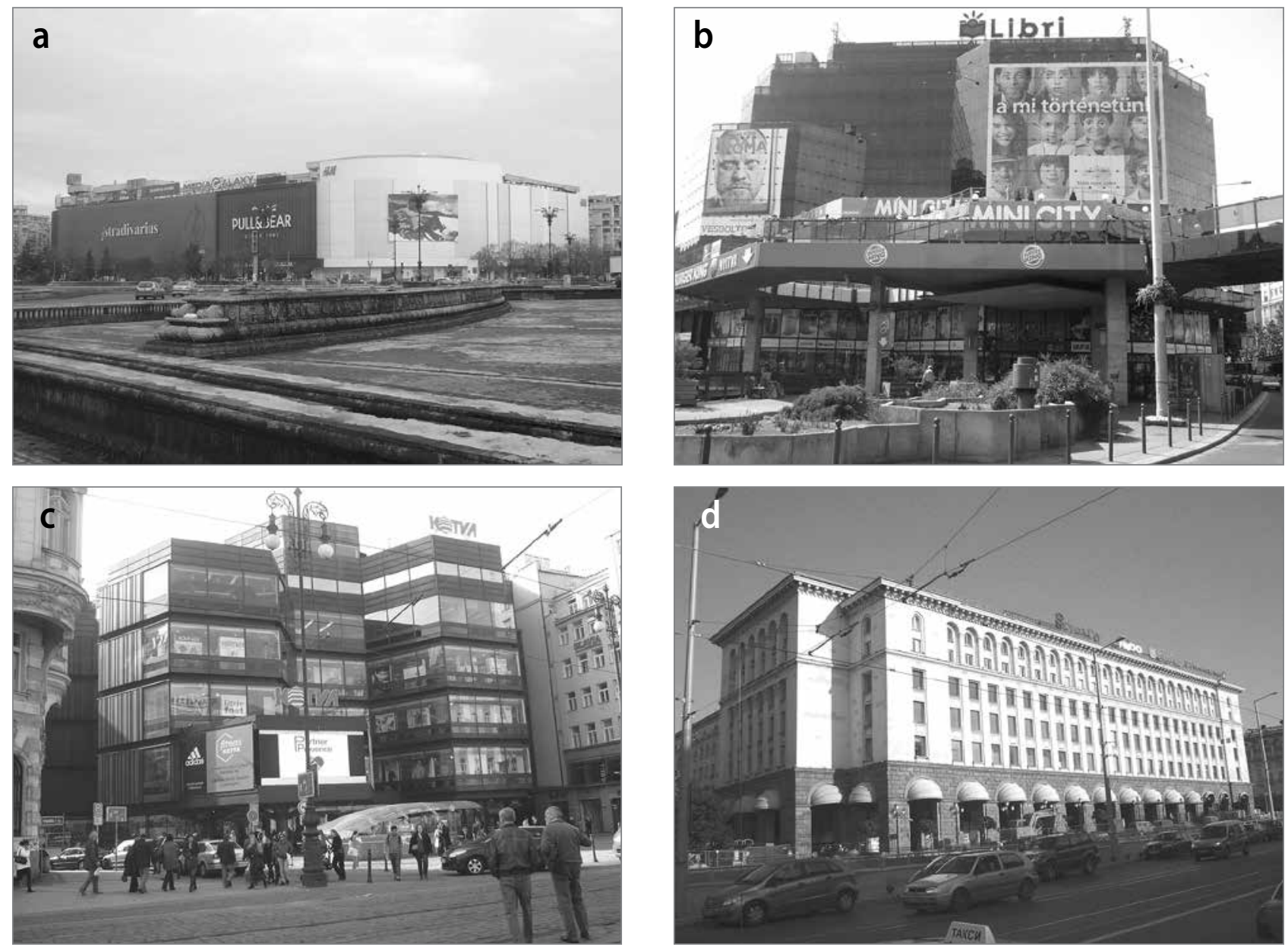

Slika 2: Središča, zgrajena pred letom 1989 v (a) Bukarešti (Unirea, 1976/1989), (b) Budimpešti (Skala Metro, 1984), (c) Pragi (Kotva, 1966-1974) in (d) Sofiji (osrednja blagovnica; 1957/2000) (foto: Jasna Mariotti).

center Unirea v Bukarešti (slika 2a), zgrajen leta 1976 in razširjen leta 1989, je veljal za največjo blagovnico socialistične Romunije. Čeprav je bil zgrajen v mestnem središču na ulici Bulevardul Unirii - mogočni mestni osi, zgrajeni za uresničitev Ceausescujeve vizije veličastne Bukarešte -, nima enakega značaja kot druge stavbe v okolici. Kljub temu je bila stavba vpliven primer romunskega potrošništva - tako po velikosti kot po videzu. Prvotna stavba je imela velika okna, danes pa so ta prekrita z veleplakati, zaradi katerih je prvotni objekt komaj še viden. Osrednja blagovnica v Sofiji je bila odprta leta 1957 kot spomenik bolgarskemu socialističnemu potrošništvu (slika 2d). Mogočna stavba, ki simbolizira modernizacijo mesta ter $s$ svojo velikostjo in površino obvladuje mestno središče, je bila zgrajena na eni od glavnih mestnih osi. Čeprav so bili ti trgovski centri preoblikovani in včasih tudi razširjeni, imajo še vedno velik vpliv v urbanem tkivu Bukarešte, Budimpešte, Prage in Sofije. Njihov videz in avtoritativni vpliv razkrivata vzorce socialističnega potrošništva v mestu, namenjenemu socialističnemu človeku.

\section{Postsocialistično prestrukturiranje mest: spreminjajoča se središča}

Preobrazba postsocialističnih mest je posledica kompleksnih družbenih, gospodarskih, kulturnih in političnih sprememb. V ozadju teh procesov je bila privatizacija (Stark, 1992; Clapham, 1995; Markuse, 1996; Grime, 1999; Stanilov, 2007, in Sendi, 2013) ali vračanje premoženja, ki je spremenilo trg in pogoje za razvoj mest. Končni rezultat teh preobrazbenih procesov je bilo zmagoslavje neoliberalizma v razvojnih vzorcih postsocialističnih mest (Sailer-Fliege, 1999; Smith in Rochovska, 2007, ter Golubchikov in Phelps, 2009). Pri postsocialistični preobrazbi Bukarešte, Budimpešte, Prage in Sofije je šlo za zgoščanje urbanega tkiva na podlagi stalnega povečevanja števila stanovanj, pisarn in trgovskih centrov.

Po padcu socializma se je stanovanjski fond $\mathrm{v}$ vseh štirih mestih stalno povečeval (preglednica 1). Bivališča, katerih število se 
Preglednica 1: Stanovanjski fond na 1.000 prebivalcev v Bukarešti, Budimpešti, Pragi in Sofiji

\begin{tabular}{llll}
\hline mesto & 1991 & 2001 & 2011 \\
\hline Bukarešta & ni podatka & 396 & 411 \\
\hline Budimpešta & 396 & 466 & 516 \\
\hline Praga & 424 & 473 & ni podatka \\
\hline Sofija & 409 & 437 & 471 \\
\hline
\end{tabular}

Vir: Czech Statistical Office in Prague (1990-2011), Hungarian Central Statistical Office in Budapest (1990-2011), National Statistical Institute in Sofia (1990-2011) in National Institute of Statistics in Bucharest (1990-2011)
Preglednica 2: Povprečno število gospodinjskih članov na popisano gospodinjstvo v Bukarešti, Budimpešti, Pragi in Sofiji

\begin{tabular}{lll}
\hline mesto & 1991 & 2011 \\
\hline Bukarešta & $2,8(1995)$ & $2,6(1999)$ \\
\hline Budimpešta & $2,2(2006)$ & $2,3(2009)$ \\
\hline Praga & 2,2 & 2,1 \\
\hline Sofija & 2,5 & 2,2 \\
\hline
\end{tabular}

Vir: Czech Statistical Office in Prague (1990-2011), Hungarian Central Statistical Office in Budapest (1990-2011), National Statistical Institute in Sofia (1990-2011) in National Institute of Statistics in Bucharest (1990-2011)

Preglednica 3: Gradbena dovoljenja, izdana v Bukarešti, Budimpešti, Pragi in Sofiji

\begin{tabular}{lllllll}
\hline mesto & 2000 & & 2005 & & 2010 \\
\hline & $\begin{array}{l}\text { stanovanjske } \\
\text { stavbe }\end{array}$ & $\begin{array}{l}\text { nestanovanjske } \\
\text { stavbe }\end{array}$ & $\begin{array}{l}\text { stanovanjske } \\
\text { stavbe }\end{array}$ & $\begin{array}{l}\text { nestanovanjske } \\
\text { stavbe }\end{array}$ & $\begin{array}{l}\text { stanovanjske } \\
\text { stavbe }\end{array}$ & $\begin{array}{l}\text { nestanovanjske } \\
\text { stavbe }\end{array}$ \\
\hline Bukarešta & ni podatka & ni podatka & 1.254 & 244 & 833 & 136 \\
\hline Budimpešta & 1.737 & 377 & 1.377 & 152 & 811 & 84 \\
\hline Praga & 7.761 & 2.383 & 7.485 & 1.832 & 4.819 & 1.783 \\
\hline Sofija & ni podatka & ni podatka & 1.226 & 387 & 596 & 205 \\
\hline
\end{tabular}

Vir: Czech Statistical Office in Prague (1990-2011), Hungarian Central Statistical Office in Budapest (1990-2011), National Statistical Institute in Sofia (1990-2011) in National Institute of Statistics in Bucharest (1990-2011)

je stalno večalo, so zapolnjevala prazna območja v teh mestih, čeprav se je njihovo prebivalstvo $\mathrm{v}$ istem obdobju spreminjalo različno hitro. Med letoma 1990 in 2010 se je prebivalstvo Bukarešte zmanjšalo za $8,59 \%$, prebivalstvo Budimpešte pa za 14,7 \%. Prebivalstvo Prage in Sofije se je povečalo za 2,95 oziroma 9,47\%, čeprav je bilo povečanje njunega stanovanjskega fonda še večje. Ti različni vrsti sprememb (to je stanovanjskega fonda in mestnega prebivalstva) sta povzročili prostorske motnje v urbanem tkivu obravnavanih mest. Deloma so bile te preobrazbe tudi posledica manjšanja velikosti gospodinjstev $\mathrm{v}$ teh mestih (preglednica 2).

V Bukarešti se je povprečno število gospodinjskih članov med letoma 1995 in 1999 zmanjšalo z 2,8 na 2,6, v Pragi in Sofiji pa se je med letoma 1991 in 2011 zmanjšalo z 2,2 na 2,1 oziroma z 2,5 na 2,2. Budimpešta je bila izjema, saj se je povprečje tam povečalo (z 2,2 na 2,3 med letoma 2006 in 2009, kar je tudi edino obdobje, za katero so bili podatki na voljo), čeprav je v enakem obdobju državno povprečje ostalo enako, in sicer 2,6.

Hkrati je upadala tudi gradbena dejavnost $\mathrm{v}$ teh mestih, kot je razvidno iz gradbenih dovoljenj, ki so bila po podatkih državnih statističnih uradov izdana med letoma 2000 in 2010 (preglednica 3). Med posameznimi mesti pa lahko opazimo razlike med gradbenimi dovoljenji, izdanimi za stanovanjske in nestanovanjske stavbe. Leta 2010 so na primer v Pragi gradbena dovoljenja za nestanovanjske stavbe predstavljala 36,9 \% dovoljenj za stanovanjske stavbe, položaj pa je bil podoben tudi
Preglednica 4: Razmerje med številom prebivalcev ter številom avtomobilov v Bukarešti, Budimpešti, Pragi in Sofiji

\begin{tabular}{llll}
\hline mesto & 1990 & 2000 & 2005 \\
\hline Bukarešta & $8,16^{*}$ & 5,01 & 4,34 \\
\hline Budimpešta & 4,28 & 3,20 & 2,84 \\
\hline Praga & 4,14 & 1,90 & 1,95 \\
\hline Sofija & ni podatka & 2,90 & 2,00 \\
\hline
\end{tabular}

Opomba: * Podatki so bili na voljo za leto 1991.

Vir: Czech Statistical Office in Prague (1990-2011), Hungarian Central Statistical Office in Budapest (1990-2011), National Statistical Institute in Sofia (1990-2011) in National Institute of Statistics in Bucharest (1990-2011)

v Sofiji, kjer je ta delež leta 2005 znašal 31,5 \%, leta 2010 pa $34,3 \%$. Nižje tovrstne odstotke lahko opazimo v Bukarešti in Budimpešti, kjer je bilo kljub padanju prebivalstva $\mathrm{v}$ istem obdobju število stanovanjskih stavb večje od števila nestanovanjskih.

Ob teh gradbenih pobudah je v obravnavanih mestih prišlo do obsežnega prostorskega prestrukturiranja, ki je bilo posledica pojava novih središč - prostorov večjega zgoščanja gospodarskih dejavnosti, ki so se po videzu in lokaciji razlikovali od tistih, zgrajenih med socializmom. $V$ postsocialističnem obdobju nova središča v obliki trgovskih centrov usmerjajo prostorsko prestrukturiranje urbanega tkiva, v katerem prevladujejo potrošniške pokrajine (Zukin, 1991). Spreminjajoči se vzorci in lokacije središč so značilnost mest na prehodu (Garb in 


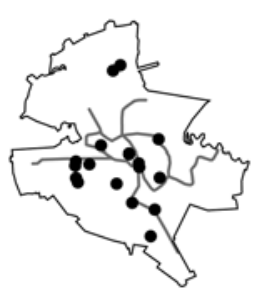

a

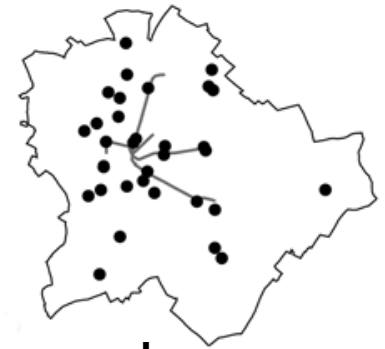

b

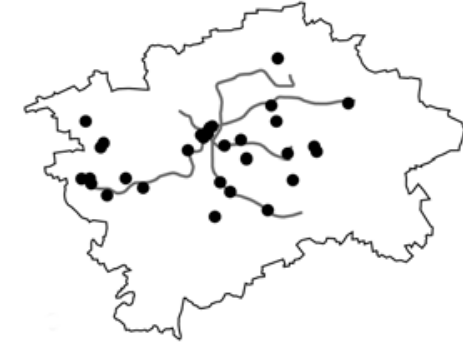

C

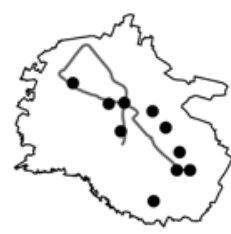

d

Slika 3: Središča, zgrajena po letu 1989 v (a) Bukarešti, (b) Budimpešti, (c) Pragi in (d) Sofiji (ilustracija: Jasna Mariotti).

Opomba: Vsa mesta so prikazana v istem merilu, pri čemer je predstavljeno njihovo trenutno upravno in načrtovalsko območje. Risbe poleg tega prikazujejo trenutne proge podzemne železnice v obravnavanih mestih in nova središča v obliki postsocialističnih trgovskih centrov.

Dybicz, 2006), raznolikost potrošniških vzorcev pa je ena od najpomembnejših značilnosti mest po padcu socializma (Sailer-Fliege, 1999, in Kreja, 2006).V takih pogojih so se v postsocialističnem kontekstu trgovska okolja v mestih spremenila, geografske omejitve, ki so obstajale med socializmom, pa so bile zaradi povečane dostopnosti in mobilnosti ublažene (Rosu in Blăgeanu, 2015).

Novi trgovski objekti v postsocialističnih mestih imajo drugačno prostorsko ureditev in sledijo drugačni lokacijski logiki: pojavljajo se v gručah ali kot izolirani subjekti blizu prog podzemne železnice. Kjer teh prog ni bilo, so bila načrtovana in zgrajena nova postajališča. Večina postsocialističnih središč je bila poleg tega postavljena blizu izvozov $\mathrm{z}$ avtocest, saj jih je bilo tako najlaže doseči z avtom. Zato se je število osebnih vozil v vseh štirih mestih po letu 1989 močno povečalo in je trenutno med največjimi v Evropi (preglednica 4). V Bukarešti se je razmerje med številom prebivalcev in številom avtomobilov med letoma 1991 in 2005 zmanjšalo z 8,16 na 4,34, v Budimpešti pa z 4,28 na 2,84. V Pragi se je med letoma 1990 in 2005 zmanjšalo z 4,14 na 1,95, v Sofiji pa z 2,9 na 2,0, kar je povečalo pritisk na mestno infrastrukturo in povzroča pogoste prometne zastoje. Deležev avtomobilov v Sofiji je trenutno med največjimi med evropskimi glavnimi mesti, in sicer ima madžarska prestolnica 546 avtomobilov na 1.000 prebivalcev (Dunaj jih ima na primer 397, London 331, Berlin 319 in Madrid 437; Sofia in figures, 2009: 8). Število avtomobilov v Bukarešti se je med letoma 1991 in 2005 povečalo za 71 \%, kar je prispevalo $\mathrm{k}$ močnemu onesnaženju mesta, ki je danes druga najbolj onesnažena evropska prestolnica, na prvem mestu je Sofija (Romania Insider, 2012).

Pojav središč v Bukarešti, Budimpešti, Pragi in Sofiji po letu 1989 kaže vzorce različne intenzifikacije funkcij znotraj urbanega tkiva in povečanje novih središč zunaj starega me- stnega jedra (slika 3). Decentralizacija trgovskih dejavnosti, znana tudi kot »trgovska revolucija « (Garb in Dybicz, 2006), je bila najočitnejša značilnost postsocialističnih mest. Razvoj obrobja so omogočile povečana povezanost, dostopnost ter interakcija med predmestjem in tradicionalnim mestnim središčem, ki sta se začela prepletati in zabrisovati obstoječe ravni hierarhije (Stefanovska, 2014). Nova središča so se razmahnila postopoma. V začetku 90. let 20. stoletja so se najprej pojavile manjše trgovine, zlasti v nekdanjih socialističnih stanovanjskih soseskah. Kmalu zatem so se v mestih začele pojavljati velike blagovnice, pri čemer je vsaka nova poskušala biti večja od prej zgrajenih, kar je povzročilo eksponentno rast. Budimpešta in Praga sta vodilni v procesu decentralizacije na podlagi novih trgovskih središč, v Bukarešti in Sofiji pa naj bi se število trgovskih centrov povečalo po koncu recesije.

Kljub opisanemu intenzivnemu razvoju so postsocialistični trgovski centri zgrajeni v zelo podobnem arhitekturnem slogu, pri čemer poskuša biti vsak center večji od prejšnjega. To se razlikuje od socialističnih arhitekturnih predhodnikov, ki so bili pionirji v gradbeništvu in so izražali določene humane vidike nakupovanja. Danes se razmeroma hitro gradijo montažne objekte, natrpane s trgovskimi dejavnostmi, ki ne izražajo nobenega razumevanja okolice ne dobrih lastnosti, temveč samo trgovsko veličastnost (slika 4).

Kljub opisanim trendom rasti poskušajo v zadnjem času v Budimpešti omejiti hitro in množično pojavljanje novih trgovskih centrov, in sicer na podlagi zakona o grajenem okolju, znanem pod imenom Plaza Stop, ki je prvi poskus nadzora gradnje trgovskih objektov. Gre za različico splošnega zakona o spremembah in zaščiti grajenega okolja iz leta 1997. V skladu z najnovejšimi spremembami je prepovedano graditi trgovske objekte, večje od $300 \mathrm{~m}^{2}$. Prav tako je prepovedana širitev obstoječih trgovskih objektov, vendar so mogoče tudi izjeme, 

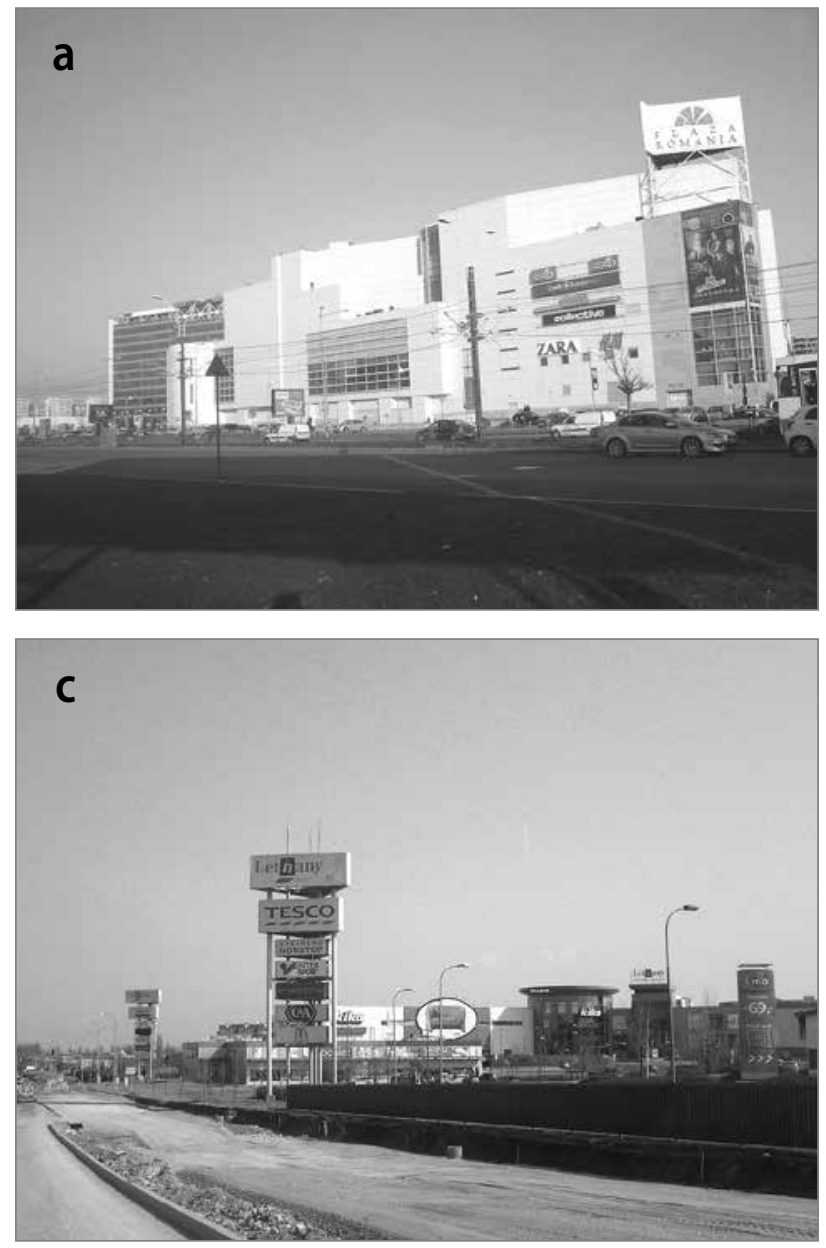

Slika 4: Središča, zgrajena po letu 1989 v (a) Bukarešti (Plaza Romania, 2005), (b) Budimpešti (Arena Plaza, 2007), (c) Pragi (Letnany, 1999) in (d) Sofiji (blagovnica, 2010) (foto: Jasna Mariotti).

ki jih mora osebno odobriti minister za gospodarstvo. Zakon je veljal od 1. januarja 2012 do konca leta 2014, rezultati tovrstnih zakonodajnih sprememb pa za zdaj še niso vidni.

Sočasno $s$ temi trendi nadzora gradnje na mestnem obrobju se v zadnjem času poskušajo oživiti tudi degradirana območja v središču Bukarešte, Budimpešte, Prage in Sofije. Od leta 2010 poteka v središču Bukarešte gentrifikacija, pri kateri se v mestno središče, ki je bilo med socializmom zapostavljeno, uvajajo nove trgovske dejavnosti. Mestni svet v Budimpešti je leta 1997 sprejel program urbane prenove, katerega cilji so bili »omogočiti obnovo stavb, infrastrukture in javnega prostora in izboljšati urbano tkivo « (Municipality of Budapest, 2002: 3). V okviru tega programa je mestna občina določila 11 ciljnih območij prenove, ki se je osredotočala na najbolj degradirane soseske v mestu, pri čemer so bili za vsako mestno okrožje določeni ustrezni ukrepi. V Pragi je urbana prenova potekala tako, da so obnovili nekdanja industrijska območja v središču mesta. Eno od teh območij, Karlin, so leta 2002 močno prizadele poplave, pri katerih je bila poplavna voda globlja od $2 \mathrm{~m}$. Čeprav so se pobude za sanacijo Karlina pojavljale že pred
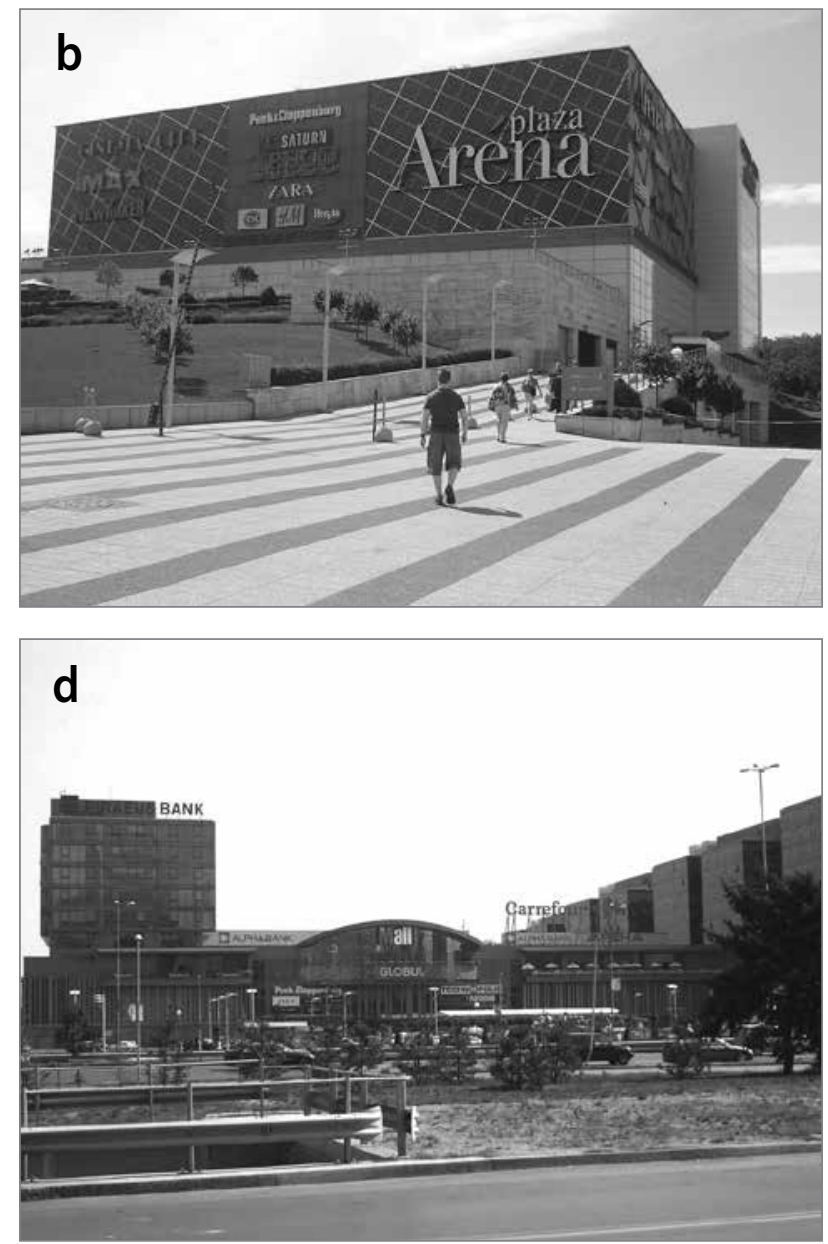

poplavami, so se naložbe vanj zares pospešile šele takoj zatem. Območje leži na bregovih reke Vltave, njegova sanacija pa je pionirski projekt prenove industrijskih območij na podlagi sanacije trgovskih in poslovnih objektov (Sykora, 2007). V Sofiji prenova mestnega središča poteka na podlagi največjega javnega posega $\mathrm{v}$ mestu, in sicer gradnje podzemne železnice, za katero se je zamisel oblikovala že med socializmom. Končni vplivi izgradnje podzemne železnice na mestno središče za zdaj še niso jasni.

\subsection{Postsocialistični urbanizem v Bukarešti, Budimpešti, Pragi in Sofiji}

Po padcu socializma so obravnavana mesta obdržala svoje stare urbanistične meje, manjše spremembe lahko $\mathrm{v}$ zadnjih letih opazimo samo v Bukarešti in Sofiji. V Pragi je bila urbanistična in upravna meja določena leta 1974, v Budimpešti pa leta 1950. Kljub temu se je prostorska zgradba teh mest korenito spremenila, saj so se iz industrijsko in proizvodno naravnanih spremenila v postindustrijska mesta, ki temeljijo na 
storitvah in trgovini. Ker je bil v teh mestih uveden postsocialistični urbanizem, se je spremenila tudi njegova institucionalna podlaga (Maier, 1998). Čeprav so bili načrtovalski in gradbeni dokumenti v obravnavanih mestih sprejeti že zelo zgodaj, so bili prvi glavni načrti sprejeti razmeroma pozno, kar kaže na vse večjo birokratizacijo načrtovalskih procesov $\mathrm{v}$ postsocialističnem obdobju. Zadnji načrt iz obdobja socializma je bil v Pragi sprejet leta 1986. Dopolnjen je bil leta 1994, prvi novi načrt po letu 1989 pa je bil sprejet leta 1999 (češ. Územní Plán hlavního mésta Prahy). Pobude za nov glavni načrt so se v Bukarešti začele leta 1994, prvi načrt po padcu Ceausescujevega režima pa je bil sprejet leta 2000 (rom. Planul Urbanistic General). V Budimpešti je bil prvi načrt po letu 1989 sprejet leta 2005 (madž. Általános rendezési tervének), čeprav so se priprave nanj začele že leta 1997, čemur je leta 1998 sledila tudi javna razprava. Odločitev za izdelavo novega načrta za Sofijo (bol. Obšc ustrojstven plan), ki naj bi usmerjal preobrazbene procese po letu 1989, je bila sprejeta že leta 1990, prvi načrt po letu 1989 pa je bil kljub temu odobren šele leta 2009. Ker so bili ti načrti sprejeti razmeroma pozno, so morali upoštevati tekoče gradbene dejavnosti $\mathrm{v}$ mestih in privatizacijske procese, ki so že bili na visoki stopnji. Ob glavnih načrtih, ki so bili izdelani za celotno ozemlje mesta in so pravzaprav načrti rabe zemljišč, je obstajalo tudi načrtovanje na lokalni ravni. Te načrtovalske pobude je sprejela in usmerjala lokalna samouprava, ki je bila odgovorna za izvajanje načrtovalskih procesov in izdajanje gradbenih dovoljenj v okviru decentralizacije načrtovalskih procesov. Danes se obravnavana mesta razlikujejo glede na poddimenzije decentralizacije (Stefanovska, 2014). Kljub temu postsocialistična gradbena dovoljenja za nova središča razkrivajo decentralizirano upravno strukturo in spreminjajoče se pristojnosti na različnih ravneh odločanja v mestih. Poleg tega se je zaradi postsocialistične decentralizacije trgovskih dejavnosti oblikovalo mesto, ki se razlikuje od tistega, ki je obstajalo še pred dvajsetimi leti; res pa je, da je dvajset let $\mathrm{v}$ zgodovini mesta kratko obdobje.

\section{Sklep: nastajanje postsocialistične evropske metropole}

V članku je obravnavana urbana preobrazba postsocialističnih mest na podlagi analize pojava središč v Bukarešti, Budimpešti, Pragi in Sofiji, pri čemer so poudarjene razlike in podobnosti med njihovimi lokacijskimi vzorci. Ugotovitve kažejo, da sta padcu socializma sledila razmah potrošništva in korenito preoblikovanje urbane pokrajine, ki sta med drugim simbolizirala demokratizacijo procesov odločanja v obravnavanih mestih. Te spremembe so povzročile intenziven pretok ljudi v novoustanovljenih gospodarskih središčih obravnavanih mest. Hkrati je z leti pojem mestnega središča izgubil svoj tradicionalni pomen; mestno središče se je iz središča družabnih in verskih dejavnosti ter prostora zgoščene politične oblasti spremenilo $\mathrm{v}$ prostor, v katerem prevladujejo gospodarske dejavnosti.

$\mathrm{Z}$ decentralizacijo postsocialističnih upravnih procesov se je odločanje v obravnavanih mestih preneslo na lokalno samoupravo. Preobrazba trgovskih objektov ni bila več del načrtovanja na ravni mestne občine, ampak se je prenesla na lokalno samoupravo, kar je ustvarilo kompleksen model medsebojnega učinkovanja urbanizma in politike na različnih ravneh odločanja.

Podobnosti med obravnavanimi mesti po padcu socializma se kažejo v razmahu novih trgovskih objektov, ki so bili zgrajeni v kratkem obdobju dvajsetih let, so številni in skoraj enakega videza. Razlike med njimi so opazne v dinamiki in jakosti rasti trgovin. Poleg tega se razlikujejo tudi vzorci njihove razpršenosti; vzorec razpršitve na mestnem obrobju je v Budimpešti opaznejši kot v Pragi, v Bukarešti pa je tesno povezan s sistemom podzemne železnice. V Sofiji model razpršitve sledi mestni osi vzhod-zahod. Te razlike so posledica različnih kulturnih identitet ter zlasti posebnosti decentralizacije in razlik $\mathrm{v}$ upravah obravnavanih mest po padcu socializma, zaradi česar je treba to temo preučevati ločeno za vsako mesto posebej.

Nova središča so ključna za razumevanje prostorskega prestrukturiranja mest po padcu socializma. Različna dinamika rasti in različni vzorci razpršitve središč so se pojavili v samo nekaj več kot dvajsetih letih; med socializmom so bili omejeni in lokalizirani, po njem pa razpršeni in okrepljeni. Po letu 1989 je premik središč na obrobje Bukarešte, Budimpešte, Prage in Sofije prispeval k ponovnemu odkritju in oblikovanju policentričnega modela mesta, kar je zmanjšalo gradnjo v starih mestnih jedrih in omogočilo enakomernejšo porazdelitev virov. Razširitev javnih prometnih omrežij in povečana mobilnost sta pospešila te vzorce razpršitve, optimizirala gradbene dejavnosti in $\mathrm{v}$ trdoživa postsocialistična mesta uvedla različne urbane funkcije.

Spreminjajoči se vzorci središč in pojav novih potrošniških prostorov sta najočitnejša znaka premika h kapitalizmu, liberaliziranemu trgu, novi politiki in svetovnim trendom urbane preobrazbe po padcu socializma. Novonastala središča v obravnavanih mestih so novi družbeni prostori z različnimi družabnimi dejavnostmi, ki prispevajo k urbanemu prestrukturiranju mest. Ceprav so na mestnem obrobju, vplivajo na intenziven razvoj v okolici in ustvarjajo sekundarno vitalnost, ki oblikuje metropolitanski življenjski slog. Tudi če ti pogoji ostajajo znotraj istih mestnih meja kot prej, so poglavitno gonilo pro- 
storskega prestrukturiranja monocentričnih socialističnih mest $\mathrm{v}$ policentrične postsocialistične metropole.

Jasna Mariotti

Queen's University Belfast, School of Planning, Architecture and Civil Engineering, Belfast, Združeno kraljestvo

E-pošta: jasna.mariotti@gmail.com

Janez Koželj

Univerza v Ljubljani, Fakulteta za arhitekturo, Ljubljana, Slovenija E-pošta: janez.kozelj@fa.uni-lj.si

\section{Viri in literatura}

Clapham, D. (1995): Privatisation and the east European housing model. Urban Studies, 32(4-5), str. 679-694. DOI: 10.1080/00420989550012834

Czech Statistical Office in Prague (1990-2011) Statistical yearbook of Prague. Praga.

Garb, Y., in Dybicz, T. (2006): The retail revolution in post-socialist central Europe and its lessons. V: Tsenkova, S., in Nedovic-Budic, Z. (ur.): The urban mosaic of post-socialist Europe, str. 231-252. Heidelberg, Physica-Verlag. DOI: 10.1007/3-7908-1727-9_12

Golubchikov, O. (2004): Urban planning in Russia: Towards the market. European Planning Studies, 12(2), str. 229-247.

DOI: 10.1080/0965431042000183950

Golubchikov, O., in Phelps, N. (2009): Post-socialist post-suburbia? Growth machine and the emergence of "edge city" in the metropolitan context of Moscow. Prispevek je bil predstavljen na konferenci z naslovom 3rd International Workshop on Post-Communist Urban Geographies »Actors Shaping Urban Change«, ki je potekala od 17. do 19. septembra v Tartuju v Estoniji. Tipkopis.

Grime, K. (1999): The role of privatization in post socialist urban transition: Budapest, Krakow, Prague and Warsaw. GeoJournal, 49(1), str. 35-42. DOI: $10.1023 / \mathrm{A}: 1007048504472$

Harloe, M. (1996): Cities in the transition. V: Andrusz, G., Harloe, M., in Szelenyi, I. (ur.): Cities after socialism - Urban and regional change and conflict in post-socialist societies, str. 1-29. Oxford, Blackwell. DOI: 10.1002/9780470712733.ch1

Hirt, S., in Kovachev, A. (2006): The changing spatial structure of post-socialist Sofia. V: Tsenkova, S., in Nedovic-Budic, Z. (ur.): The urban mosaic of post-socialist Europe: Space, institutions and policy, str. 113-130. Heidelberg, Physica-Verlag. DOI: 10.1007/3-7908-1727-9_6

Hoxha, V., Dimitrovska Andrews, K., in Temeljotov Salaj, A. (2014): Cultural factors affecting urban planners' intentions to regulate public space in Prishtina, Kosovo. Urbani izziv, 25(2), str. 76-89.

DOI: 10.5379/urbani-izziv-en-2014-25-02-001

Hungarian Central Statistical Office in Budapest (1990-2011) Statistical yearbook of Budapest. Budimpešta.

Kádár, B. (2013): Differences in the spatial patterns of urban tourism in Vienna and Prague. Urbani izziv, 24(2), str. 96-111. DOI: 10.5379/urbani-izziv-en-2013-24-02-002

Kok, H., in Kovacs, Z. (1999): The process of suburbanization in the agglomeration of Budapest. Netherlands Journal of Housing and the Built Environment, 14(2), str. 119-141. DOI: 10.1007/BF02496818

Kos, D. (2010): Prostorsko urejanje med stroko in piarom. Teorija in praksa, 47(2-3), str. 413-434.
Koželj, J. (1992): O krizi urbanizma in izhodih iz nje. Urbani izziv, 19, str. 20-25.

Koželj, J. (2007): Opredelitev sodobnega mesta. V: Cerpes, l., in Desman, M. (ur.): O urbanizmu: Kaj se dogaja s sodobnim mestom, str. 195208. Ljubljana, Založba Krtina.

Kreja, K. (2006): Spatial imprints of urban consumption: Large scale retail development in Warsaw. V: Tsenkova, S., in Nedovic-Budic, Z. (ur.): The urban mosaic of post-socialist Europe, str. 253-272. Heidelberg, Physica-Verlag. DOI: 10.1007/3-7908-1727-9_13

Leetmaa, K., in Tammaru, T. (2007): Suburbanization in countries in transition: Destinations of suburbanizers on the Tallinn metropolitan area. Geografiska Annaler: Series B, Human Geography, 89(2), str. 127-146. DOI: 10.1111/j.1468-0467.2007.00244.x

Maier, K. (1998): Czech planning in transition: Assets and deficiencies. International Planning Studies, 3(3), str. 351-365. DOI: $10.1080 / 13563479808721719$

Mandič, S., in Filipovič Hrast, M. (2015): Alternatives to social housing: Applicants' views of various policy options. Urbani izziv, 26(1), str. 6982. DOI: 10.5379/urbani-izziv-en-2015-26-01-001

Marcuse, P. (1996): Privatization and its discontents: Property rights in land and housing in the transition in eastern Europe. V: Andrusz, G., Harloe, M., in Szelenyi, I. (ur.): Cities after socialism - Urban and regional change and conflict in post-socialist societies, str. 119-191. Oxford, Blackwell. DOI: 10.1002/9780470712733.ch5

Municipality of Budapest (2002) Urban Renewal Programme: Budapest 2002. Budimpešta.

Musil, J. (1980): Urbanization in socialist countries. White Plains, NY, M. E. Sharpe.

Musil, J. (1993): Changing urban systems in post-communist societies in central Europe: Analysis and prediction. Urban Studies, 30(6), str. 899906. DOI: 10.1080/00420989320080841

Musil, J. (2005): City development in central and eastern Europe before 1990: Historical context and socialist legacies. V: Hamilton, I. F. E., Dimitrovska Andrews, K., in Pichler-Milanovic, N. (ur.): Transformation of cities in central and eastern Europe: Towards globalization, str. 22-43. Tokio, United Nations University Press.

National Institute of Statistics in Bucharest (1990-2011): Statistical yearbook of Bucharest. Bukarešta.

National Statistical Institute (2009): Sofia in figures 2009. Dostopno na: www.sofia.bg (sneto 10. 9. 2015).

National Statistical Institute in Sofia (1990-2011): Sofia in figures. Sofija.

Nedovic-Budic, Z., Tsenkova, S., in Marcuse, P. (2006): The urban mosaic of post-socialist Europe. V: Tsenkova, S., in Nedovic-Budic, Z. (ur.): The urban mosaic of post-socialist Europe: Space, institutions and policy, str. 3-20. Heidelberg, Physica-Verlag. DOI: 10.1007/3-7908-1727-9_1

Romania Insider (2012): Bucharest, second most polluted capital in Europe but ranks better then Paris on green areas, 17 May 2012. Dostopno na: http://www.romania-insider.com (sneto 10. 9. 2015).

Rosu, L. I., in Blăgeanu, A. (2015): Evaluating issues and performance of a public transport network in a post-communist city using a quantitative spatial approach. Urbani izziv, 26(2), str. 103-116. DOI: 10.5379/urbani-izziv-en-2015-26-02-002

Sailer-Fliege, U. (1999): Characteristics of post-socialist urban transformation in east central Europe. GeoJournal, 49(1), str. 7-16. DOI: 10.1023/A:1006905405818 
Sendi, R. (2013): The low housing standard in Slovenia: Low purchasing power as an eternal excuse. Urbani izziv, 24(1), str. 107-124. DOI: 10.5379/urbani-izziv-en-2013-24-01-002

Smith, A., in Rochovska, A. (2007): Domesticating neo-liberalism: Everyday lives and the geographies of post-socialist transformations. Geoforum, 38(6), str. 1163-1178. DOI: 10.1016/j.geoforum.2007.03.003

Stanilov, K. (2007): Taking stock of post-socialist urban development: A recapitulation. V: Stanilov, K. (ur.): The post-socialist city: Urban form and space transformations in central and eastern Europe after socialism, str. 3-20. Dordrecht, Springer. DOI: 10.1007/978-1-4020-6053-3_1

Stark, D. (1992): Path dependence and privatization strategies in east central Europe. East European Politics and Societies, 6, str. 17-54. DOI: $10.1177 / 0888325492006001003$

Stefanovska, J. (2014): Planning the post-socialist city: Urban transformations and changing centralities after socialism. Doktorska disertacija. Ljubljana, Univerza v Ljubljani, Fakulteta za arhitekturo.

Stefanovska, J., in Koželj, J. (2012): Urban planning and transitional development issues: The case of Skopje, Macedonia. Urbani izziv, 23(1), str. 91-100. DOI: 10.5379/urbani-izziv-en-2012-23-01-002

Sykora, L. (1998): Commercial property development in Budapest, Prague and Warsaw. V: Enyedi, G. (ur.): Social change and urban restructuring in central Europe, strt. 109-136. Budimpešta, Akadémiai Kiadó.

Sykora, L. (2007): Office development and post-communist city formation: The case of Prague. V: Stanilov, K. (ur.): The post-socialist city: Urban form and space transformations in central and eastern Europe after socialism, str. 117-145. Dordrecht, Springer.

DOI: 10.1007/978-1-4020-6053-3_7

Szelenyi, I. (1996): Cities under socialism - and after. V: Andrusz, G., Harloe, M., in Szelenyi, I. (ur.): Cities after socialism - Urban and regional change and conflict in post-socialist societies, str. 286-317. Oxford, Blackwell.

Tsenkova, S. (2010): Informal settlements in post-communist cities: Diversity factors and patterns. Urbani izziv, 21(2), str. 73-84.

DOI: 10.5379/urbani-izziv-en-2010-21-02-001

Tsenkova, S. (2011): Venturing into unknown territory: Strategic spatial planning in post-communist cities. Urbani izziv, 22(1), str. 83-99. DOI: 10.5379/urbani-izziv-en-2011-22-01-001

Tsenkova, S. (2014): The housing policy nexus and people's responses to housing challenges in post-communist cities. Urbani izziv, 25(2), str. 90-106. DOI: 10.5379/urbani-izziv-en-2014-25-02-002

United Nations Population Division (2015): World population prospects 2008. Dostopno na: http://esa.un.org (sneto 11. 9. 2015).

Zukin, S. (1991): Landscapes of power: From Detroit to Disney World. Berkley, University of California Press. 